\title{
Looking for Sin in All the Wrong Places: An Empirical Investigation of the Affluenza Construct
}

\author{
Peter Lorenzi \\ Jason Q. Zhang \\ Loyola University Maryland \\ Roberto Friedmann \\ University of Georgia
}

\begin{abstract}
Sin taxes, popular source of tax revenue, are best applied to antisocial and inelastic consumption. But what consumption behaviors are antisocial and addictive? This research examines the assumption that excessive antisocial consumption - affluenza is addictive. Four hundred fourteen subjects completed a measure of affluenza. Analysis identified six factors: materialism, overspending, urgency, financial stress, shopaholicism, and self-centeredness. The results showed little evidence of the hypothesized level of affluenza in the American working population, with some limited impact of age, gender and education. Politicians looking for sins to tax may be looking in all the wrong places.
\end{abstract}

\section{Introduction}

In a period of declining corporate profits, retail sales, and tax revenues, consumptionbased sin taxes have become a popular alternative method of taxation. Rather than tax income, wealth or general consumption, "sin" taxes target antisocial behavior. The conventional wisdom is that taxing antisocial behavior has the potential to produce new government revenue and - in some cases - to reduce the taxed behavior.

Augustine and Aquinas recognized that there is broad, gray area that separates just taxation and legalized plunder (Todd, 2008). But tough economic times cause governments to seek new sources of revenue. This intensified search for revenue can cause politicians to explore areas previously outside their typical consideration. Tax increases on income have become widely unpopular. Consumption taxes have increased in popularity, yet with sales taxes reaching double-digit figures in many countries in the world, they are almost universally disliked from the outset. Thus the appeal of sin taxes, as they allegedly focus only on types of consumption that society overtly frowns upon. And yet, though certainly not a new idea, the evidence and historical antecedents of taxing "sin" and/or consumption behaviors that have negative consequences to both society and the individual, is indeed equivocal to the point that it warrants additional attention and research so as to enhance our understanding. 
As richly documented by Altman (2009), from Pope Leo X in the 1500s taxing licensed prostitutes, to Peter the Great taxing Russian men who grew beards, the sin tax has been an established practice for a considerable time. Throughout history, since the Puritans levied taxes on morally suspect items such as liquor, tobacco, tea and meat pies (Baxandall, 2003) the application of sin taxes has had debatable results, and often even great outcry associated with it. When Alexander Hamilton proposed an excise tax on alcohol it sparked the Whiskey Rebellion and an uprising by Pennsylvania settlers had to be squashed. Most recently, due to the public outcry very recently New York Governor David Paterson backtracked on plans to raise taxes on goods ranging from downloading pornography to soft drinks.

One fundamental argument suggested by many (e.g., Baldwin, 2004), is that instead of society outlawing certain "bad behaviors", an action or policy which so often creates significant pushback, why not tax them? As in the management of environmental problems, with the pollution and enormous waste associated with commuting in American freeways; whereas environmentalists would like to allow carpoolers use the fast lane and forbid solo commuters from doing so, economists often suggest putting a stiff tax on the fast lane, and let anyone willing to pay use it. The economic perspective on sin taxes cannot be easily dismissed, as it has been often shown that outright prohibitions due to legislation can have substantial undesirable consequences and fail to reduce the consumption of the commodity in question. Instead, the proposed argument is that taxation with additional regulations can be more likely to reduce the undesirable consumption, as supported by the evidence of the prohibition of alcohol in the US, 1920-1933, where neither consumption nor prices of alcohol changed in a significant manner (Miron, 1998). Adding fuel to the debate on taxation is the question of the magnitude of such tax. A proposed tax hike in Japan in 2002 was shown that, as originally suggested, with a resulting per-pack of cigarettes cost of $\$ 2.50,16 \%$ of nicotine-dependent Japanese would quit. Yet, if the tax increase would hike the price of cigarettes to about $\$ 8.00$ per pack, as in New York, some $62 \%$, or 28 million of Japanese smokers would quit (Bremmer, 2002). Obviously, the magnitude of such increase would create a remarkable "loud" reaction from the population at risk. Yet, one needs to keep in mind that, even with such projections, and as has been shown in terms of price elasticity of demand for alcohol and tobacco, only subgroups of the targeted population of addicted consumers will show significant responses to drastic price increases. Ayyagari, Deb, Fletcher, Gallo, \& Sindelar (2009) show that in case of significant price increases, some unresponsive groups of consumers might indeed drink more heavily, so the price increase very much fails to curb the targeted behavior in those most likely to cause negative externalities. Furthermore, in cases where the addicted individual is also in control of a household budget, sin tax hikes can further negatively affect the welfare of the rest of the household members through the addict's reallocation of the family budget, or indirectly, via higher health expenses due to substitution of cheaper and lower quality alcohol and tobacco products (Mohamed \& Black, 2006).

It is important to note that whereas alcohol and tobacco have been the most common product categories that have attracted sin taxes both in the US as well as overseas 
(Carter \& Chapman, 2006; Crawford, 1997; Dahlby \& Chandoevwit, 2007; Mohamed \& Black, 2006) there are a number of other products such as: pornography (online, videos and magazines), fatty foods, marijuana, high-fructose corn syrup, caffeine, and trans fats; where excess consumption and addiction have already been targeted (e.g., Gulli, 2006). The same is true for behaviors with negative societal consequences such as polluting, gambling and prostitution (e.g., Altman, 2009; Baldwin, 2004; Rauber, 2008; Schorr, 1998).

When looking at the consumers' decision processes leading to excessive or addictive consumption, one fundamental assumption behind sin taxes is that higher taxes on addictive goods should increase overall welfare by assisting consumers with self-control problems and or individuals who have trouble resisting "temptation". Yet, as in the differential price elasticity responses mentioned above, research systematically finds segments of targeted populations that have very low self-control and/or use high discount rates and are quite unresponsive to price hikes, as in the case of cigarettes. As such, those with the least willpower need the most help, and being unresponsive to taxes, their behaviors strongly suggest that other policies might be needed (Fletcher, Partha, \& Sindelar, 2009). Nonetheless, many proponents of sin taxes would argue that even in the face of low self-control, sin taxes may improve total social surplus and consumer welfare as long as the excess taxation revenue is returned via reinvestments to the population segments being addressed (e.g., O'Donoghue \& Rabin 2006). A good example of this, is the suggestion that even though most video game manufacturers already have a ratings system for violence in games, imposing a tax of $3 \%$ on the most violent game versions within that 30 billion dollar industry, would provide the US government a significant amount to spend on American children (Bissell, 2004).

Extending such logic, it has been argued that many behavioral economists are currently trying to justify a new form of paternalism. Whitman and Rizzo (2007) claim that consumers are not fully rational decision makers as traditional economists would like to suggest, and instead, they exhibit cognitive problems such as status-quo, optimism bias, hindsight bias, context dependence and other characteristics which lead them to behave in manners that do not advance their own best interest. Thus, it is precisely at this stage, when consumption behaviors exhibited are far from those desired, that governments can potentially intervene so as to improve consumer welfare. The extreme stage of this logic ends up being what has been referred to as the government acting as a nanny-state (Crawford, 1997), playing a very salient role in guiding behavior.

Beyond the mere economic appeal and foundation as a revenue source, there is also a moral argument for sin taxes that goes hand-in-hand with the raw fiscal need of governments to augment their tax collections. Lorenzi $(2006,2008)$ defined sin taxes as those government revenues from the consumption of services and products that generally exhibit three characteristics: first, the behavior exhibits an inelastic demand curve; second, the behavior is self-destructive or harmful to the individual in question, and third, the behavior is harmful to others. So, if a society can indeed reduce the number and/or magnitude of behaviors that fall under these characteristics, it is not only 
enhancing its own collective welfare, but also assisting its citizens in a very positive manner.

Yet, in the analysis of sin taxes from a moral and societal-ethics perspective, a vicious cycle becomes evident, and the economics of sin taxes come to the forefront yet again. One can easily see that today's sin taxes are triggered by what Baxandall (2003) calls the twin logics of public health and budget politics. Again, the underlying premise is that efforts to discourage sinful behaviors by raising prices of sinful products makes people healthier, but at the same time fills governmental coffers. Considering that sin taxes do not assess responsible consumers of these products differently than irresponsible ones; that there are other policies that can also discourage harmful and addictive consumption while improving public health (e.g., Beshears, Choi, Laibson, \& Madrian, 2006); and that very often the sin tax burdens are disproportionately absorbed by the poorest segments of society, the inevitable reality is that sooner, rather later, in trying to manage or curb addictions governments often succeed in establishing yet another form of addiction: governments hooked on the proceeds of addictions (Schorr, 1998). The moral and ethical dilemma is more than justified.

The practical issue then, is to find a politically and economically satisfactory method of taxation that raises revenue without reducing the underlying economic activity, and does not trigger a moral/ethical unwanted consequence.

\section{Research Questions}

Are Americans addicted to consumption? Given the historical evidence and predisposition of using sin taxes to address addictive behaviors, consider then the merits of extending this logic to probably what would be the most encompassing and ultimate consumption addiction, as would be the case with an addiction to consumption. From almost every corner of the popular press, to political and religious figures, the harsh criticism of America as a land of overconsumption and excesses materialism is not only prevalent, but also seemingly ever-present for the last few decades. The idea of a society, and in particular the American society being addicted to consumption is intuitively appealing; is justified as the most extreme manifestation of addictive consumption behavior, and if nothing else, should be interesting to investigate empirically being such a commonly accepted and shared notion.

Studies focusing on materialism and compulsive consumption help lay a solid metatheoretical justification for looking at consumption at the point where it reaches addictive characteristics. As pointed out by Burroughs and Rindfleisch (2002), materialism has been addressed across disciplines as varied as public policies (e.g., Easterlin \& Crimmins, 1991), political science (e.g., Inglehart, 1990), social psychology (e.g., Kasser \& Ryan, 1993), and consumer research (e.g., Belk, 1984; Belk, 1985; Fournier \& Richins, 1991; Richins \& Dawson, 1992; Fournier \& Guiry, 1993).

Compulsive buying (e.g., O'Guinn \& Faber, 1989; Faber et al., 1995; DeSarbo \& Edwards, 1996; Faber \& O'Guinn, 2008) has been defined as a chronic, abnormal form 
of shopping and spending characterized, in the extreme, by an overpowering, uncontrollable, and repetitive urge to buy, with disregard for the consequences, and as "a chronic, repetitive purchasing that becomes a primary response to negative feelings and that provides immediate short-term gratification, but which ultimately causes harm to the individual and/or others" (Faber \& O'Guinn, 2008, p. 1004). Compulsive consumption develops over time; linked to a variety of traits (e.g., dependence, depression, lack of impulse control, fantasy, self-esteem, excitement-seeking, anxiety) and has been linked to addiction (e.g., Hirschmann, 1992); it has been characterized by a denial of consequences (e.g., Rook, 1985; Faber, O'Guinn \& Krych, 1987; Rook \& Hoch, 1987). Some authors have suggested compulsive buying is an either-or condition (e.g., Valence, D'Astous \& Fortier, 1988; Faber \& O'Guinn, 1989; 1992; 2008); others have suggested compulsive buying may lie a long a continuum (e.g., Albanese, 1988).

Building on the literature of materialism and compulsive buying, de Graaf, Wann \& Naylor (2005) coined the term "affluenza" to describe the "disease" associated with allconsuming consumption or materialism. Affluenza indicates a very high degree of materialism, excessive consumption, and negligent waste. Affluenza is therefore presented as antisocial behavior, for it affects others and the environment, and not just the perpetrator of the behavior.

This research explores antisocial behavior-an addiction to consumption-that may meet the criteria for sin taxes. The objective of this study is to understand the affluenza construct developed by de Graaf, Wann \& Naylor (2005), to examine its prevalence, and to empirically test its power as a potential basis for sin taxes.

In the original instrument (presented in Table 1), de Graaf, Wann \& Naylor (2005) employed fifty self-descriptive questions that asked respondents to each item with either a "yes" or "no" answer. Those respondents scoring in the first quartile (39 to 50 'yes' answers) are labeled as "keen on dying to keep up appearances"; those in the second quartile (26 to 38 positive answers) as "a typical American consumer"; those in the third quartile (13 to 25 agreements) as having "a reasonable level of consumption"; and those in the fourth or bottom quartile (12 or fewer agreements) as being "a very frugal minimalist."

\section{Analysis}

Data

Yes-no scaling choices preclude important differences and incremental levels of behavior. Scaling adjustments resulted. Revising the initial scaling to a six-point Likert scale, where 1 = never, 2 = rarely, $3=$ sometimes, 4 = usually, 5 = almost always, and 6 $=$ always, allowed for important distinctions in descriptions of behavior. The authors employed thirty research assistants who individually solicited 414 subjects to complete the re-scaled, fifty-item survey. Research assistants had great independence and discretion in collecting the data. They targeted adults. The target population was an employed, educated adult population, with sample demographic confirming a sample 
Table 1

Personal Lifestyle Survey $(n=414)$

\begin{tabular}{|c|c|c|c|}
\hline Item & M & 1 & 6 \\
\hline $\begin{array}{l}\text { 1. Do you get bored unless you have something to consume } \\
\text { (goods, good, media)? }\end{array}$ & 2.56 & 72 & 11 \\
\hline $\begin{array}{l}\text { 2. Do you try to impress your friends with what you own, or } \\
\text { where you vacation? }\end{array}$ & 1.86 & 157 & 2 \\
\hline 3. Do you ever use shopping as "therapy"? & 2.13 & 177 & 8 \\
\hline $\begin{array}{l}\text { 4. Do you sometimes go to the mall just to look around, with } \\
\text { nothing specific to buy? }\end{array}$ & 2.32 & 137 & 8 \\
\hline $\begin{array}{l}\text { 5. Do you buy home-improvement products in a large chain } \\
\text { store rather than the neighborhood hardware store? }\end{array}$ & 4.25 & 22 & 5 \\
\hline 6. Have you ever gone on a vacation primarily to shop? & 1.25 & 345 & 74 \\
\hline $\begin{array}{l}\text { 7. In general, do you think about things more than you think } \\
\text { about people? }\end{array}$ & 2.12 & 94 & 0 \\
\hline $\begin{array}{l}\text { 8. When you pay utility bills do you ignore the amount of } \\
\text { resources consumed? }\end{array}$ & 3.36 & 70 & 3 \\
\hline $\begin{array}{l}\text { 9. Given the choice between a slight pay raise and a shorter } \\
\text { workweek, would you choose the money?' }\end{array}$ & 2.90 & 98 & 54 \\
\hline $\begin{array}{l}\text { 10. Do you personally fill more than one large trash bag in a } \\
\text { single week? }\end{array}$ & 3.01 & 75 & 45 \\
\hline $\begin{array}{l}\text { 11. Have you ever lied to a family member about the amount } \\
\text { you spent for a product? }\end{array}$ & 2.35 & 104 & 49 \\
\hline 12. Do you frequently argue with family members about money? & 2.12 & 126 & 10 \\
\hline $\begin{array}{l}\text { 13. Do you volunteer less than five hours a week to help other } \\
\text { people? }\end{array}$ & 3.50 & 51 & 6 \\
\hline $\begin{array}{l}\text { 14. Do you routinely compare the appearance of your lawn or } \\
\text { home with others in your neighborhood? }\end{array}$ & 2.58 & 116 & 69 \\
\hline $\begin{array}{l}\text { 15. Does each person in your house or apartment occupy more } \\
\text { than } 500 \text { square feet of personal space? }\end{array}$ & 3.36 & 114 & 22 \\
\hline 16. Do you routinely gamble or buy lottery tickets? & 1.88 & 193 & 111 \\
\hline 17. Do you check your investments at least once a day? & 2.17 & 185 & 13 \\
\hline 18. Are any of your credit cards maxed out? & 1.31 & 347 & 24 \\
\hline 19. Do worries about debt cause you $p$ & 1.66 & 252 & 4 \\
\hline
\end{tabular}




\begin{tabular}{||l|r|r|r||}
\hline \multicolumn{1}{|l|}{ headaches or indigestion? } & & & \\
\hline $\begin{array}{l}\text { 20. Do you spend more time shopping every week than you do } \\
\text { with your family? }\end{array}$ & 1.28 & 327 & 7 \\
\hline 21. Do you frequently think about changing jobs? & 2.43 & 119 & 2 \\
\hline $\begin{array}{l}\text { 22. Have you had cosmetic surgery to improve your } \\
\text { appearance? }\end{array}$ & 1.13 & 388 & 21 \\
\hline $\begin{array}{l}\text { 23. Do your conversations often gravitate toward things you } \\
\text { want to buy? }\end{array}$ & 2.30 & 77 & 3 \\
\hline $\begin{array}{l}\text { 24. Are you sometimes ashamed about how much money you } \\
\text { spend on fast food? }\end{array}$ & 1.75 & 234 & 4 \\
\hline $\begin{array}{l}\text { 25. Do you sometimes weave back and forth in traffic to get } \\
\text { somewhere faster? }\end{array}$ & 2.85 & 55 & 9 \\
\hline \begin{tabular}{|l|r|r} 
26. Have you ever experienced road rage? \\
\hline 27. Do you feel like you're always in a hurry?
\end{tabular} & 2.64 & 66 & 19 \\
\hline $\begin{array}{l}\text { 28. Do you often throw away recyclable materials rather than } \\
\text { take the time to recycle them? }\end{array}$ & 3.30 & 16 & 15 \\
\hline 29 Do you spend less than an hour a day outside? & 46 & 26 \\
\hline $\begin{array}{l}\text { 30 Are you unable to identify more than three wildflowers that } \\
\text { you native to your area? }\end{array}$ & 2.77 & 63 & 29 \\
\hline $\begin{array}{l}\text { 31. Do you replace sports equipment before it's worn out in } \\
\text { order to have the latest styles? }\end{array}$ & 1.78 & 217 & 989 \\
\hline 32. Does each member of your family have his or her own TV? & 3.77 & 131 & 168 \\
\hline $\begin{array}{l}\text { 33. Is the price of a product more important to you than how well } \\
\text { it was made? }\end{array}$ & 2.32 & 118 & 2 \\
\hline $\begin{array}{l}\text { 34. Has one of your credit cards been rejected by a salesperson } \\
\text { because were over limit? }\end{array}$ & 1.21 & 356 & 2 \\
\hline 35. Do you receive more than five mail-order catalogs a week? & 2.18 & 209 & 34 \\
\hline $\begin{array}{l}\text { 36. Are you one of the consumers who almost never take a } \\
\text { reusable bag to grocery stores? }\end{array}$ & 4.10 & 102 & 197 \\
\hline 37. Do you ignore the miles per gallon of gasoline your car gets? & 2.61 & 143 & 40 \\
\hline $\begin{array}{l}\text { 38. Did you choose the most recent car you bought partly } \\
\text { because if enhanced your self-image? }\end{array}$ & 1.73 & 248 & 9 \\
\hline 39. Do you have more than five active credit cards? & 1.56 & 335 & 23 \\
\hline $\begin{array}{l}\text { 40. When you get a raise at work, do you immediately think } \\
\text { about how you can spend it? }\end{array}$ & 2.46 & 135 & 24 \\
\hline 41. Do you drink more soft drink, by volume, than tap water? & 2.29 & 213 & 44 \\
\hline 42. Did you work more this year than last year? & 107 & 87 \\
\hline
\end{tabular}




\begin{tabular}{|c|c|c|c|}
\hline $\begin{array}{l}\text { 43. Do you have doubts that you'll be able to reach your } \\
\text { financial goals? }\end{array}$ & 2.80 & 87 & 24 \\
\hline 44. Do you feel "used up" at the end of your workday? & 3.18 & 39 & 25 \\
\hline $\begin{array}{l}\text { 45. Do you usually make just the minimum payment on credit } \\
\text { card bills? }\end{array}$ & 1.80 & 239 & 13 \\
\hline $\begin{array}{l}\text { 46. When you shop, do you often feel a rush of euphoria } \\
\text { followed by anxiety? }\end{array}$ & 1.77 & 217 & 6 \\
\hline $\begin{array}{l}\text { 47. Do you sometimes feel as though your personal expenses } \\
\text { are so demanding that you can't afford public expenses like } \\
\text { schools, parks, and transit? }\end{array}$ & 1.74 & 231 & 5 \\
\hline 48. Do you have more stuff than you can store in your house? & 2.19 & 189 & 22 \\
\hline 49. Do you watch TV more than two hours a day? & 2.99 & 72 & 38 \\
\hline \multirow[t]{2}{*}{ 50. Do you eat meat nearly every day? } & 4.19 & 31 & 111 \\
\hline & 123.5 & 7656 & 1627 \\
\hline
\end{tabular}

representative of the target. Each respondent was asked to provide a telephone number to help researchers ensure data integrity with a follow up phone call audit. Although no audits were performed, each survey had a different phone number. The result was a convenience sample deemed representative of the population described by de Graaf et al. (2005) as being afflicted with affluenza.

In the final sample, two hundred thirteen of the subjects (51.4\%) were male. Twenty-two percent of all subjects had less than a college education; $60 \%$ had a four-year college degree; and $18 \%$ had a graduate degree. Twelve percent of the subjects were between 19 and 22 years old; $31 \%$ were 23 to 28 years old; $27 \%$ were between 29 and 39 ; and $30 \%$ were over 39 . The sample represented an educated, American working adult population.

Summing the fifty answers on their survey, the possible range of raw scores was 50 to 300 , with ascending quartiles commencing at $50,112.5,175$, and 237.5 , respectively. The raw grand mean $(n=414)$ was 123 ; the mean percentile score was $30.6 \%$, placing the score in the second quartile, in significant contrast to the assumption by de Graaf, Wann, and Naylor (2005) that the mean would be in the top quartile.

Dividing the sample by gender, age, and education demonstrated some differences, and several very small cells. Males with a graduate degree and over age 39 scored lowest $(117, n=17)$. Males with less than a college degree between the ages of 23 and 28 scored highest $(136, n=3)$. Female subjects exhibited the same pattern, with the eight women over the age of 39 and with a graduate degree scoring lowest (109) and 
the four women between the ages of 23 and 28 with less than a college degree scored highest (151).

Might we have different results were only the extreme responses considered, per the original conceptualization? Scoring only always and never, the frequencies of always (item score of 6) and never (item score of 1) responses generated scores in Table 1. The mean level of 'never' responses was $37 \%$. The mean level of 'always' responses was $7.8 \%$. Respondents were five times as likely to have never engaged in affluenza behaviors to have ever engaged in such behaviors. There were no meaningful differences across demographic groups for the 'never' and 'always' responses. The overall pattern of evidence obtained by these general results, suggest a much lower actual level of affluenza than de Graaf et al. (2005) assumed. They believed that Americans would score in the top quartile. In our study, subjects scored just above the bottom quartile.

\section{Factor Analysis}

The raw data provided some basis for concern as well as opportunity for further analysis. Correlations among the fifty items showed numerous negative correlations and correlations among the fifty items were small. The instrument lacked convergent validity. We therefore reduced the number of items and excluded those "orphan" items that were not closely correlated with any other items. The resulting sample included only twentyone items that were correlated with at least another item with a correlation larger than 0.3 .

With these items, a principal component factor analysis was performed to extract patterns in the data. The overall Measure of Sampling Adequacy (MSA) of our data was 0.78 , suggesting it was appropriate to conduct factor analysis. This factor analysis revealed six potential dimensions in the data based on the goodness-of-fit statistics. These six dimensions (Table 2), ranked in descending order of importance, were labeled as materialism, over-spending, urgency, financial stress, shopaholism, and selfcenteredness. Affluenza has been described as an illness; these six dimensions are explicit symptoms of this illness.

\section{Results}

Averaging item scores in a dimension produced a composite dimension score. Averaging the scores across six dimensions produced an overall affluenza score. The revised instrument and factor analysis produced an affluenza score for each respondent. Respondents, significantly, scored at the low end of the affluenza scale, about two (out of 6 ) and the maximum score was about four. The percentile distribution (Figure 1) approximates a normal distribution with the majority of respondents cluster around 2 . There was scant evidence to support a hypothesis that American consumers demonstrate affluenza. 


\begin{tabular}{|c|c|c|}
\hline \multicolumn{3}{|c|}{$\begin{array}{l}\text { Table } 2 \\
\text { Labels for Affluenza Dimensions }\end{array}$} \\
\hline Labels & $\begin{array}{c}\text { Item } \\
\text { Number }\end{array}$ & $\begin{array}{c}\text { Importance } \\
\text { in Explaining } \\
\text { Affluenza }\end{array}$ \\
\hline Materialism & $2,7,23,31,38$ & 1 \\
\hline Over-spending & $11,18,34,45$ & 2 \\
\hline Urgency & $25,26,27$ & 3 \\
\hline Financial stress & $12,19,43,44$ & 4 \\
\hline Shopaholism & $4,6,46$ & 5 \\
\hline Self-centeredness & 20,22 & 6 \\
\hline
\end{tabular}

Figure 1

\section{Distribution of Affluenza Scores}

Distribution of Individual Affluenza Score

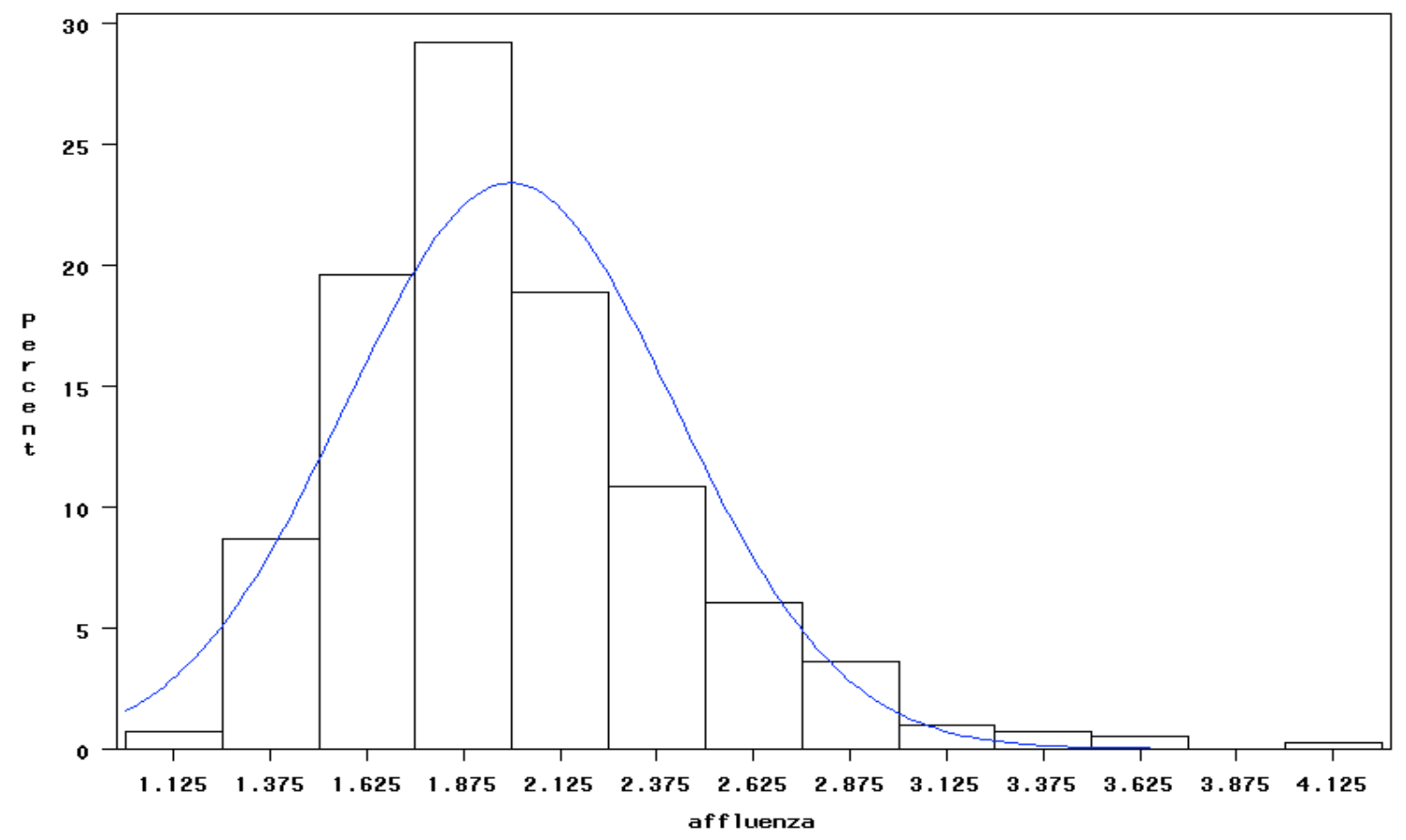


Using demographic variables and the six extracted affluenza dimensions provided the basis for further analysis (ANOVA) to understand the different patterns of affluenza across demographic segments. Table 3 shows the results of this analysis, with the mean for each level of a demographic variable and the standard deviation in parenthesis and two-tailed tests.

Table 3

ANOVA Analysis of Six Affluenza Dimensions

\begin{tabular}{|c|c|c|c|c|c|c|c|c|c|c|c|c|c|}
\hline \multirow[b]{2}{*}{$\begin{array}{l}\text { Dependent } \\
\text { measure }\end{array}$} & \multicolumn{3}{|c|}{ Gender } & \multicolumn{5}{|c|}{ Age } & \multicolumn{5}{|c|}{ Education (Degree) } \\
\hline & M & $\mathbf{F}$ & Sig & $19-22$ & $23-28$ & $29-39$ & $40+$ & Sig. & H. S. & Assoc & Bach & Grad & Sig. \\
\hline Materialism & $\begin{array}{l}2.07 \\
(0.70)\end{array}$ & $\begin{array}{c}1.83 \\
(0.54)\end{array}$ & * & $\begin{array}{c}2.1 \\
(0.74)\end{array}$ & $\begin{array}{l}2.11 \\
(0.69)\end{array}$ & $\begin{array}{l}2.02 \\
(0.58)\end{array}$ & $\begin{array}{c}1.68 \\
(0.51)\end{array}$ & * & $\begin{array}{c}1.78 \\
(0.62)\end{array}$ & $\begin{array}{c}1.81 \\
(0.66)\end{array}$ & $\begin{array}{l}2.02 \\
(0.65)\end{array}$ & $\begin{array}{l}1.95 \\
(0.57)\end{array}$ & * \\
\hline $\begin{array}{l}\text { Over- } \\
\text { spending }\end{array}$ & $\begin{array}{c}1.65 \\
(0.73)\end{array}$ & $\begin{array}{c}1.67 \\
(0.62)\end{array}$ & n.s. & $\begin{array}{l}1.88 \\
(0.80)\end{array}$ & $\begin{array}{c}1.82 \\
(0.80)\end{array}$ & $\begin{array}{l}1.58 \\
(0.58)\end{array}$ & $\begin{array}{c}1.48 \\
(0.47)\end{array}$ & * & $\begin{array}{c}1.74 \\
(0.69)\end{array}$ & $\begin{array}{c}1.97 \\
(1.13)\end{array}$ & $\begin{array}{c}1.63 \\
(0.62)\end{array}$ & $\begin{array}{c}1.55 \\
(0.56)\end{array}$ & * \\
\hline Urgency & $\begin{array}{c}3.01 \\
(0.97) \\
\end{array}$ & $\begin{array}{c}2.84 \\
(0.91) \\
\end{array}$ & n.s. & $\begin{array}{c}3.08 \\
(1.01) \\
\end{array}$ & $\begin{array}{c}3.2 \\
(0.91) \\
\end{array}$ & $\begin{array}{c}2.98 \\
(0.86) \\
\end{array}$ & $\begin{array}{c}2.52 \\
(0.82) \\
\end{array}$ & * & $\begin{array}{c}2.69 \\
(0.99) \\
\end{array}$ & $\begin{array}{c}2.86 \\
(0.98) \\
\end{array}$ & $\begin{array}{c}3.09 \\
(0.96) \\
\end{array}$ & $\begin{array}{c}2.62 \\
(0.71) \\
\end{array}$ & * \\
\hline $\begin{array}{l}\text { Financial } \\
\text { stress }\end{array}$ & $\begin{array}{c}2.42 \\
(0.86)\end{array}$ & $\begin{array}{l}2.45 \\
(0.75)\end{array}$ & n.s. & $\begin{array}{l}2.45 \\
(0.97)\end{array}$ & $\begin{array}{l}2.35 \\
(0.75)\end{array}$ & $\begin{array}{l}2.55 \\
(0.81)\end{array}$ & $\begin{array}{l}2.41 \\
(0.81)\end{array}$ & n.s. & $\begin{array}{l}2.51 \\
(0.82)\end{array}$ & $\begin{array}{c}2.63 \\
(1.21)\end{array}$ & $\begin{array}{c}2.42 \\
(0.75)\end{array}$ & $\begin{array}{l}2.33 \\
(0.84)\end{array}$ & n.s. \\
\hline Shopaholism & $\begin{array}{l}1.57 \\
(0.60)\end{array}$ & $\begin{array}{l}1.99 \\
(0.73)\end{array}$ & * & $\begin{array}{c}1.94 \\
(0.82)\end{array}$ & $\begin{array}{c}1.9 \\
(0.75)\end{array}$ & $\begin{array}{c}1.79 \\
(0.73)\end{array}$ & $\begin{array}{l}1.55 \\
(0.48)\end{array}$ & * & $\begin{array}{c}1.75 \\
(0.66)\end{array}$ & $\begin{array}{c}1.82 \\
(0.84)\end{array}$ & $\begin{array}{l}1.79 \\
(0.71)\end{array}$ & $\begin{array}{c}1.72 \\
(0.64)\end{array}$ & n.s. \\
\hline $\begin{array}{l}\text { Self- } \\
\text { centeredness }\end{array}$ & $\begin{array}{l}1.14 \\
(0.45)\end{array}$ & $\begin{array}{c}1.25 \\
(0.53)\end{array}$ & * & $\begin{array}{l}1.38 \\
(0.87)\end{array}$ & $\begin{array}{c}1.22 \\
(0.46)\end{array}$ & $\begin{array}{l}1.15 \\
(0.47)\end{array}$ & $\begin{array}{c}1.13 \\
(0.30)\end{array}$ & * & $\begin{array}{l}1.16 \\
(0.51)\end{array}$ & $\begin{array}{c}1.3 \\
(0.72)\end{array}$ & $\begin{array}{l}1.19 \\
(0.48)\end{array}$ & $\begin{array}{c}1.2 \\
(0.42)\end{array}$ & n.s. \\
\hline $\begin{array}{l}\text { Overall } \\
\text { Affluenza } \\
\text { score }\end{array}$ & $\begin{array}{c}1.98 \\
(0.44)\end{array}$ & $\begin{array}{l}2.01 \\
(0.41)\end{array}$ & n.s. & $\begin{array}{c}2.14 \\
(0.57)\end{array}$ & $\begin{array}{c}2.1 \\
(0.42)\end{array}$ & $\begin{array}{l}2.01 \\
(0.40)\end{array}$ & $\begin{array}{c}1.8 \\
(0.31)\end{array}$ & * & $\begin{array}{l}1.94 \\
(0.45)\end{array}$ & $\begin{array}{l}2.07 \\
(0.61)\end{array}$ & $\begin{array}{c}2.02 \\
(0.40)\end{array}$ & $\begin{array}{c}1.89 \\
(0.38)\end{array}$ & n.s. \\
\hline
\end{tabular}

Across gender, three dimensions of affluenza showed significant differences.

Specifically, male consumers were more likely to be materialistic whereas females were more likely to be engaged in shopaholism and self-centeredness behaviors. The overall affluenza score did not appear to be different across male and female consumers.

Across the levels of age cohorts, and except for the dimension of financial stress, all five other dimensions of affluenza were significantly different. Scores for: materialism, overspending, urgency, shopaholism, and self-centeredness fell significantly for consumers over the age of forty. The overall affluenza score also showed the same pattern. In sum, compared to other age groups, Americans over the age of forty are less likely to engage in affluenza.

For materialism, over-spending, and urgency, consumers exhibited higher scores as their education level increased. And, interestingly, the scores started to fall for consumers with graduate degrees. People with graduate education might be more discriminating and/or rational, and thus perhaps more likely to make informed decisions - instead of going along with the excessive consumption trends of the society. The 


\section{Table 4}

\section{Six-factor Affluenza Scale}

\begin{tabular}{|c|c|}
\hline Factor & Item \\
\hline \multirow[t]{5}{*}{ Materialism } & $\begin{array}{l}\text { 1. Do you try to impress your friends with what you own, or where } \\
\text { you vacation? }\end{array}$ \\
\hline & $\begin{array}{l}\text { 2. Do your conversations often gravitate toward things you want to } \\
\text { buy? }\end{array}$ \\
\hline & $\begin{array}{l}\text { 3. Do you replace sports equipment before it's worn out in order to } \\
\text { have the latest styles? }\end{array}$ \\
\hline & $\begin{array}{l}\text { 4. Did you choose the most recent car you bought partly because if } \\
\text { enhanced your self-image? }\end{array}$ \\
\hline & $\begin{array}{l}\text { 5. In general, do you think about things more than you think about } \\
\text { people? }\end{array}$ \\
\hline \multirow[t]{4}{*}{ Overspending } & $\begin{array}{l}\text { 6. Has one of your credit cards been rejected by a salesperson } \\
\text { because were over limit? }\end{array}$ \\
\hline & $\begin{array}{l}\text { 7. Do you usually make just the minimum payment on credit card } \\
\text { bills? }\end{array}$ \\
\hline & $\begin{array}{l}\text { 8. Have you ever lied to a family member about the amount you } \\
\text { spent for a product? }\end{array}$ \\
\hline & 9. Are any of your credit cards maxed out? \\
\hline \multirow[t]{3}{*}{ Urgency } & $\begin{array}{l}\text { 10. Do you sometimes weave back and forth in traffic to get } \\
\text { somewhere faster? }\end{array}$ \\
\hline & 11. Have you ever experienced road rage? \\
\hline & 12. Do you feel like you're always in a hurry? \\
\hline \multirow[t]{4}{*}{$\begin{array}{l}\text { Financial } \\
\text { Stress }\end{array}$} & $\begin{array}{l}\text { 13. Do you have doubts that you'll be able to reach your financial } \\
\text { goals? }\end{array}$ \\
\hline & 14. Do you feel "used up" at the end of your workday? \\
\hline & 15. Do you frequently argue with family members about money? \\
\hline & $\begin{array}{l}\text { 16. Do worries about debt cause you physical symptoms like } \\
\text { headaches or indigestion? }\end{array}$ \\
\hline \multirow[t]{2}{*}{ Shopaholism } & $\begin{array}{l}\text { 17. Do you sometimes go to the mall just to look around, with nothing } \\
\text { specific to buy? }\end{array}$ \\
\hline & $\begin{array}{l}\text { 18. When you shop, do you often feel a rush of euphoria followed by } \\
\text { anxiety? }\end{array}$ \\
\hline
\end{tabular}




\begin{tabular}{|c|c|}
\hline & 19. Have you ever gone on a vacation primarily to shop? \\
\hline \multirow{2}{*}{$\begin{array}{l}\text { Self- } \\
\text { centeredness }\end{array}$} & 20. Have you had cosmetic surgery to improve your appearance? \\
\hline & $\begin{array}{l}\text { 21. Do you spend more time shopping every week than you do with } \\
\text { your family? }\end{array}$ \\
\hline
\end{tabular}

overall affluenza score, however, was not significantly different across levels of education.

Based on the six dimensions (Table 4), we further analyzed American consumers' affluenza based on select demographics in a regression model. With the overall affluenza score being the dependent variable, independent variables included all three demographic variables (i.e., Gender, Age, and Education), and two square terms (i.e., $\mathrm{Age}^{2}$ and Education $^{2}$ ) in order to capture the curvilinear relationships. The results of this model suggest that age and education had an inverted U-shape relationship with affluenza. While the level of affluenza tends to increase with age and education, this trend turns downward when consumers grow older or become more educated. There is no evidence to suggest that affluenza is inelastic. The results showed little affluenza, with some impact of age, gender and education. Additional research to identify inelastic, antisocial behavior is needed. Politicians are looking for sin - to tax it. They just may be looking in all the wrong places.

\section{Conclusions}

This research examined excessive consumption patterns among adult Americans, using the affluenza survey developed by de Graaf, et al. (2005). The research results indicate little to no evidence of any affluenza pandemic. Analysis of the original affluenza instrument produced a modified, six-dimension instrument with twenty-one items to measure affluenza. Analysis using the revised instrument again suggested a relatively low level of excessive consumption among American consumers.

With the revised instrument, this research further analyzed American consumers' tendency of affluenza with their demographics. Intriguing patterns of affluenza tendency were identified. We found that several affluenza dimensions varied greatly by gender, age, and education. Most interestingly, both age and education had an inverted Ushape relationship with affluenza tendency. This analysis helps relate different levels of affluenza tendency to specific demographic groups. These findings expand our understanding of a complex construct with potentially many valuable public policy and consumer welfare implications.

Drawing a parallel to studies on consumer behavior studies that focus on financial situations (e.g., Kim \& Lee, 2005; Kim \& Lyons, 2008), research on addiction to consumption may have a great potential on further understanding consumption behaviors, and if so, to have a similar effect on an a wide array of subsequent public policy and consumer welfare issues. However, it is surprising to note that the notion of consumption as an addiction has not received nearly as much attention as other topics 
that relate to consumer welfare and/or have strong public policy implications. Among others, examples of such topics are: consumers' diets in the context of their health and safety (e.g., Binkley, 2006; Kemp, Burton, Creyer, \& Suter, 2007; Knight \& Warland, 2004; Mason, Scammon, \& Fang, 2007; Moore \& Rideout, 2007), consumer privacy (e.g., Larose \& Rifon, 2007; Milne, Rohm \& Bahl, 2004; Nehf, 2007; Norberg, Horne, \& Horne, 2007), consumer protection (e.g., Burton, 2006; Lyons, Rachlis, \& Scherpf, 2007; Rotfeld, 2003, 2006; Sovern, 2004;), direct to consumer advertising (e.g., Cohen, 2002; Lexchin \& Mintzes, 2002; Royne \& Myers, 2008; Sheehan, 2003), and smoking (e.g., Albaum, Baker, Hozier, \& Rogers, 2002; Beltramini \& Bridge, 2001; Smith \& Stutts, 2006; Wolburg, 2006).

The conclusion that American affluenza is non-existent may be premature given the still unrefined aspects of the instrument, and the lack of a complete understanding of the construct. The results obtained represent first steps to better understand affluenza and to offer a baseline to study the intensity of consumption and the possibility of a social conscience. More important, the implications for tax policy are profound: If there is no addiction to $\sin$, sin taxes will produce little revenue, especially if the social message is as strong as the financial penalty.

Affluenza is not prevalent nor is it apparently addictive. In looking for addictive, antisocial behaviors to tax, politicians need to look elsewhere. Some bad habits are not that 'bad', nor are they necessarily addictively 'habitual'. Somewhat addictive bad habits can be changed with time, education, practice and incentives. For sin taxes, we suggest that politicians focus on behaviors that are addictive, antisocial, and self-destructive. In extreme cases, the 'tax' could be a prohibition. However, many antisocial behaviors are so enduring, pervasive and addictive that a financial tax can be an effective way to generate some public benefit from antisocial behavior. The tax can also deter the behavior, if only in a limited fashion.

The results suggest examples of acts worthy of closer examination as sin tax candidates include prostitution, pornography, marijuana, cocaine, and gambling. While some may object to this apparent injection of morals into the marketplace, many economists have long recognized economics as a moral, not just a mathematical, science. There is a mathematical and moral argument for sin taxes, increasing both economic and social capital.

\section{References}

Albanese, P. J. (1988). The intimate relations of the consistent consumer:

Psychoanalytic object relations theory applied to economics. New York, NY: Praeger.

Albaum, G., Baker, Jr., K. G., Hozier, G. C., \& Rogers, R. D. (2002). Smoking behavior, information services, and consumption values of teenagers: Implications for public policy and other intervention failures. Journal of Consumer Affairs, 36(1), 50-65.

Altman, A. (2009). A brief history of: sin taxes. Time, 173(14), 14. 
Ayyagari, P., Deb, P., Fletcher, J. M., Gallo, B., \& Sindelar, J. L. (2009). Sin taxes: Do heterogeneous responses undercut their value? NBER Working Paper, w15124.

Baldwin, W. (2004). In praise of sin taxes. Forbes, 173(10), 22.

Baxandall, P. (2003). Taxing habits. Regional Review, 13(1), 19-26.

Belk, R. W. (1984). Three scales to measure constructs related to materialism: Reliability, validity, and relationships to measures of happiness in Advances in Consumer Research, Vol. 11. In T. Kinnear (Ed.), Association for Consumer Research, 29 (pp. 291-297). Provo, UT.

Belk, R. W. (1985). Materialism: Trait aspects of living in the material world. Journal of Consumer Research, 12, 265-280.

Beltramini, R. F., \& Bridge, P. D. (2001). Relationship between tobacco advertising and youth smoking: Assessing the effectiveness of a school-based, antismoking intervention program. Journal of Consumer Affairs, 35, 263-277.

Beshears, J., Choi, J. J., Laibson, D. I., \& Madrian, B. C. (2006). Early decisions: A regulatory framework. NBER Working Paper, w11920.

Binkley, J. K. (2006). The effect of demographic, economic, and nutrition factors on the frequency of food away from home. Journal of Consumer Affairs, 40, 372-391.

Bissell, M. (2004). Proper sin tax? Christian Science Monitor, 96(250), 9.

Burroughs, J. E., \& Rindfleisch, A. (2002). Materialism and well-being: A conflicting values perspective. Journal of Consumer Research, 29, 348-370.

Burton, M. J. (2006). When to hold 'em; when to fold 'em: Choosing consumer protection battles. Journal of Consumer Affairs, 40, 186-195.

Carter, S. M., \& Chapman, S. (2006). Smokers and non-smokers talk about regulatory options in tobacco control. Tobacco Control, 15, 398-404.

Cohen, J. B. (2002). Introductory comments: Direct-to-consumer prescription drug advertising: Evaluating regulatory policy in the United States and New Zealand. Journal of Public Policy \& Marketing, 21, 172-173.

Crawford, W. (1997). Taxing for health? Consumers' Research Magazine, 80(10), 34.

Dahlby, B., \& Chandoevwit, W. (2007). The marginal cost of public funds for excise taxes in Thailand. eJournal of Tax Research, 5(1), 135-167.

De Graaf, J., Wann, D., \& Naylor, T. H. (2005). Affluenza: The all-consuming epidemic. San Francisco, CA: Berrett-Kohler.

Desarbo, W. S., \& Edwards, E. A. (1996). Typologies of compulsive buying behavior: A constrained clusterwise regression approach. Journal of Consumer Psychology, $5,231-262$.

Easterlin, R. A., \& Crimmins, E. M. (1991). Private materialism, personal self-fulfillment, family life, and public interest: The nature, effects, and causes of recent changes in the values of American youth. Public Opinion Quarterly, 55, 499-533.

Faber, R. J., \& O'Guinn, T. C. (1989). Classifying compulsive consumers: Advances in the development of a diagnostic tool. Advances in Consumer Research, 16, 738744.

Faber, R. J., \& O'Guinn, T. C. (1992). A clinical screener for compulsive buying. Journal of Consumer Research, 19, 459-469.

Faber, R. J., \& O'Guinn, T. C. (2008). Compulsive buying: Review and reflection. In C. P. Haugtvedt, P. M. Herr \& F. R. Kardes (Eds.), Handbook of Consumer Psychology (pp. 1039-1056). New York, NY: Psychology Press. 
Faber, R. J., \& O'Guinn, T. C., \& Krych, R. (1987). Compulsive consumption. Advances in Consumer Research, 14, 132-135.

Fletcher, J. M., Deb, P., \& Sindelar, J. L. (2009). Tobacco use, taxation and self control in adolescence. NBER Working Paper, w15130.

Fournier, S., \& Guiry, M. (1993). An emerald green jaguar, a house on Nantucket, and an African safari: Wish lists and consumption dreams in materialist society. Association for Consumer Research (McAlister, L. \& Rothschild, M. L., Eds.), 352-358.

Fournier, S., \& Richins, M. L. (1991). Some theoretical and popular notions concerning materialism. Journal of Social Behavior and Personality, 6, 403-414.

Gulli, C. (2006). The next sin tax? Maclean's, 119(3), 45.

Hirschmann, E. C. (1992). The consciousness of addiction: Toward a general theory of compulsive consumption. Journal of Consumer Research, 19, 155-179.

Inglehart, R. (1990). Culture shift in advanced industrial society. Princeton, NJ: Princeton University Press.

Kasser, T., \& Ryan, R. M. (1993). A dark side of the American dream: Correlates of financial success as a central life aspiration. Journal of Personality and Social Psychology, 65, 410-422.

Kemp, E., Burton, S., Creyer, E. H., \& Suter, T. A. (2007). When do nutrient content and nutrient content claims matter?: Assessing consumer tradeoffs between carbohydrates and fat. Journal of Consumer Affairs, 41, 47-73.

Kim, H., \& Lee, J. (2005). Unequal effects of elders' health problems on wealth depletion across race and ethnicity. Journal of Consumer Affairs, 39, 148-172.

Kim, H., \& Lyons, A.C. (2008). No pain, no strain: Impact of health on the financial security of older Americans. Journal of Consumer Affairs, 42, 9-36.

Knight, A., \& Warland, R. (2004). The relationship between sociodemographics and concern about food safety issues. Journal of Consumer Affairs, 38, 107-120.

Larose, R., \& Rifon, N. J. (2007). Promoting I-safety: Effects of privacy warnings and privacy seals on risk assessment and online privacy behavior. Journal of Consumer Affairs, 41, 127-149.

Lexchin, J., \& Mintzes, B. (2002). Direct-to-consumer advertising of prescription drugs: The evidence says no. Journal of Public Policy \& Marketing, 21, 194-201.

Lorenzi, P. (2006). The moral grounds of sin taxes. Society, 44(1), 67-71.

Lorenzi, P. (2008). Affluence, consumption and the American lifestyle. Society, 45(2), 107-111.

Lyons, A. C., Rachlis, M., \& Scherpf, E. (2007). What's in a score? Differences in consumers' credit knowledge using OLS and quantile regressions. Journal of Consumer Affairs, 41, 223-249.

Mason, M., Scammon, D. L., \& Fang, X. (2007). The impact of warnings, disclaimers, and product experience on consumers' perceptions of dietary supplements. Journal of Consumer Affairs, 41, 74-99.

Milne, G. R., Rohm, A. J., \& Bahl, S. (2004). Consumers' protection of online privacy and identity. Journal of Consumer Affairs, 38, 217-232.

Miron, J. A. (1998). An economic analysis of alcohol prohibition. Journal of Drug Issues, 28(3), 741-762. 
Mohamed, Ai, \& Black, P. (2006). Sin taxes and poor households: Unanticipated effects. South African Journal of Economics, 74(1), 131-136.

Moore, E. S., \& Rideout, V. J. (2007). The online marketing of food to children: Is it just fun and games? Journal of Public Policy \& Marketing, 26, 202-220.

Nehf, J. P. (2007). Shopping for privacy on the internet. Journal of Consumer Affairs, 41, 351-375.

Norberg, P. A., Horne, D. R., \& Horne, D. A. (2007). The privacy paradox: Personal information disclosure information versus behaviors. Journal of Consumer Affairs, 41, 100-126.

O'Donoghue, T., \& Rabin, M. (2006). Optimal sin taxes. Journal of Public Economics, 90(10-11), 1825-1849.

O'Guinn, T. C., \& Faber, R. J. (1989). Compulsive buying: A phenomenological exploration. Journal of Consumer Research, 16, 147-157.

Rauber, P. (2008). Hating the sin. Sierra, 93(1), 22.

Richins, M. L., \& Dawson, S. (1992). A consumer values orientation for materialism and its measurement: Scale development and validation. Journal of Consumer Research, 19, 303-316.

Rook, D. W. (1985). The buying impulse. Journal of Consumer Research, 14, 189-199.

Rook, D. W. \& Hoch, S. J. (1987). Consuming impulses. Advances in Consumer Research, 12, 23-27.

Rotfeld, H. J. (2003). Desires versus the reality of self-regulation. Journal of Consumer Affairs, 37, 424-427.

Rotfeld, H. J. (2006). Depending on the kindness of strangers. Journal of Consumer Affairs, 40, 407-410.

Royne, M. B., \& Myers, S. D. (2008). Recognizing consumer issues in dtc pharmaceutical advertising. Journal of Consumer Affairs, 42, 60-80.

Schorr, D. (1998). Sin taxes are no answer to addictions. Christian Science Monitor, 90(114), 22.

Sheehan, K. B. (2003). Balancing acts: An analysis of food and drug administration letters about direct-to-consumer advertising violations. Journal of Public Policy \& Marketing, 22, 159-169.

Smith, K. H., \& Stutts, M. A. (2006). The influence of individual factors on the effectiveness of message content in antismoking advertisements aimed at adolescents. Journal of Consumer Affairs, 40, 261-293.

Sovern, J. (2004). Stopping identity theft. Journal of Consumer Affairs, 38, 233-243.

Todd, C. (2008). The ethical basis for taxation in the thought of Thomas Aquinas. Journal of Markets \& Morality, 11(1), 41-57.

Valence, G., D’Astous, A. \& Fortier, L. (1988). Compulsive buying: Concept and measurement. Journal of Consumer Policy, 11, 419-433.

Wolburg, J. M. (2006). College students' responses to antismoking messages, denial, defiance, and other boomerang effects. Journal of Consumer Affairs, 40, 294-323.

Whitman, D. G., \& Rizzo, M. J. (2007). Paternalist slopes. NYU Journal of Law \& Liberty, 07-08. 